レーザー技術ノート

\author{
自己較正型X線ボロメーターを用いた \\ 軟X線プレートの絶対感度較正 \\ 砂原 淳*.西村 博 明*.米田仁紀**.中井貞 雄* \\ (1995年3月6日＼cjkstart受理)

\begin{abstract}
Absolute Calibration of Soft X-ray Plates by Using A Self-Calibrated X-ray Bolometer
\end{abstract}

Atsushi SUNAHARA * , Hiroaki NISHIMURA * , Hitoki YONEDA ** , Sadao NAKAI*

(Received March 6, 1995)

\begin{abstract}
The sensitivity of soft X-ray plates, Kodak 101-05 and ILFORD Q-PLATE at $1.1 \mathrm{keV}$ was measured by using a self-calibrated X-ray bolometer as a standard detector for absolute measurements of soft X-rays. Cross-calibration was also made by using an X-ray sensitive diamond detector. Good agreement in the absolute sensitivity was obtained between the bolometer and the diamond detector.
\end{abstract}

Key Words: Absolute soft X-ray measuremsnt, Kodak 101-05 plate, ILFORD Q-plate, $\gamma$-curve, X-ray, Bolometer, Diamond detector

1.はじめに

レーザー生成プラズマより発生する高輝度X線 はX線リソグラフィー1), X線レーザー2), X線 マイクロスコピー3), 間接照射型爆縮核融合 ${ }^{4)}$ 等, 様々な分野で幅広く応用されている。従来 これらのX線の検出にはX線フィルム ${ }^{5)}, \mathrm{X}$ 線真 空ダイオード6), 高速半導体検出器7), 蛍光体/ マイクロチャンネルプレート ${ }^{8}$ 等が用いられて きたが, これらの検出器を用いて発光スペクト ルを正確に測定し, 絶対光量を押さえるために は, 検出器の分光感度や絶対感度, 飽和特性を 知る必要がある。
検出器の絶対感度を較正するためには適当な $\mathrm{X}$ 線源と感度の既知な基準検出器が必要であ る。例えばX線フィルムに対しては較正用X線 源として軟X線管が, 基準検出器として比例計 数管が一般的に用いられて来た ${ }^{9)}$ 。しかし測定 対象のX線強度がX線管から放出されるX線と 極端に異なる場合は相反則不規 ${ }^{10)}$ の問題が生 じ，較正源の時間幅スケールと観測対象とする 現象の時間スケールをそろえた感度較正法を用 いなければならない。このためレーザープラズ マX線を観測対象とする限りにおいて, 連続発 生型のX線管や高繰り返しパルスによる準連続 発生型のシンクロトロン放射光に代わって, 単

*大阪大学レーザー核融合研究センター (†565吹田市山田丘2-6)

**電気通信大学レーザー極限技術研究センター ( 182 東京都調布市調布ヶ丘1-5-1)

* Institute of Laser Engineering Osaka University (Yamadaoka 2-6, Suita, Osaka 565)

**Institute for Laser Science,University of Electro-Communications, (1-5-1, Chofugaoka, Chofu, Tokyo 182) 
一パルス状のレーザープラズマX線源で較正す る必要が生じた。一方, 基準検出器として蛍光 体/マイクロチャンネルプレートやX線真空ダ イオードを考えた時, X線吸収端の存在により 分光感度は複雑な構造を持ち, また表面酸化な どに伴う長期的な安定性に問題があるため基準 検出器としては不向きである。またシリコン半 導体検出器では軟X線の吸収長が〜 $1000 \AA$ 程度 と短いために表面準位や格子久陥, 表面の污れ 等によって分光感度が左右され, その構造も複 雑になるなどの問題があり,やはり絶対感度を 与える基準検出器としては問題が多い。このよ うな背景から分光感度が平坦で, 経時変化もな く, しかも外部較正源を用いずに自己絶対感度 較正を行うことができる基準検出器が求められ ていた。そこで今回, 自己較正の可能なボロメー ター ${ }^{11)}$ 製作し，X線プレート(Kodak社 10105plate, ILFORD社Q-plate)の絶対感度較正を 行った。併せて測定法の妥当性を確認する目的 で光導電性素子であるダイヤモンド検出 $\mathrm{a}^{\mathrm{a}}{ }^{12,13)}$ を較正実験時に併用し, 応答並びに感 度の相互比較を行った。その結果, X線入力に 対するボロメーター及びダイヤモンド検出器の 出力は線形性, 絶対感度ともに良い一致が得ら れた。

\section{2. 軟X線絶対計測用ボロメーター}

ボロメーターとはX線などの輻射や粒子束を 吸収体に吸収させ，この温度上昇を何らかの方 法で検出して吸収エネルギーを測定する検出器 である。吸収体や吸収体の温度上昇を検出する 測温法には, 測定する輻射や粒子のエネルギー 域や用途に応じて種々のものが存在する。今回 対象とするのは軟X線領域であるので軟X線に 対してフラットな分光特性となるように吸収体 にはAuを用いた。測温法としては測温抵抗体 や熱電対，ピエゾ素子を用いる等の方法がある が, 感度の自己較正を行う観点から今回は測温 抵抗体を採用した。この測温抵抗体に対しても 温度係数の高さや経年的安定性, 製作技術上の 観点から Auを材料として用いた。一般にレー
ザーショットにより発生するX線による温度上 昇はきわめて小さいため $\left(\sim 0.001{ }^{\circ} \mathrm{K}\right)$, 測温抵 抗体の温度上昇信号を記録可能なレベルまで増 幅する必要があり, この過程で混入するノイズ をいかに抑制するかがボロメーター検出器の性 能を決める重要なポイントとなる。このノイズ の成分として測温抵抗体のバイアス電流による 温度上昇に起因した熱雑音や, 増幅部から生じ る固有のノイズ及びレーザープラズマを生成し たときに生ずる外部ノイズなどがあり，それぞ れに対して低減対策が必要である。増幅部に関 しては一段目にチョッパーアンプを採用し，さ らに外来のノイズの混入を防ぐためにローパ ス，ハイパスのフィルターを挿入することによ りボロメーターの応答時定数にほぼ一致する 5 10 Hz付近で増幅利得が最大となるような 周波数特性に設定した。この他, 増幅部の電源 や測温抵抗体のバイアス電源にもノイズフィル ターを組み込み，ノイズの混入を極力抑えた回 路構成となっている。

ボロメーターの自己感度較正は測温抵抗体に パルス状の電流を流し, 吸収体の温度上昇を引 き起こすことにより行った。この方法は吸収体 と測温抵抗体の温度平衡がこれらの泠却時間ス ケールに比べて速やかにとれる限りにおいて妥 当であり, 各種のカロリーメーター較正に採用 されている方法である。吸収体と測温抵抗体と の熱平衡のモデル解析に関しては詳しい研究が なされており ${ }^{14)}$ 検出部の設計にはこれらの結 果を参考にした。

\section{1 試作した装置の構成}

Fig. 1に試作したボロメーターの構成を示す。 装置は吸収体と測温抵抗体からなる検出部, 測 温抵抗体の抵抗值の変化を電圧の変化に変換す るブリッジ部, 微小な電位変動をオシロスコー プで測定できるレベルまで上昇させる増幅部, ショット時のプラズマ粒子やターゲット蒸気に よる吸収体の冷却を防止する真空排気系からな る。Fig. 2に本装置の写真を示す。検出部に直 結された増幅回路基板と真空排気装置が見え 


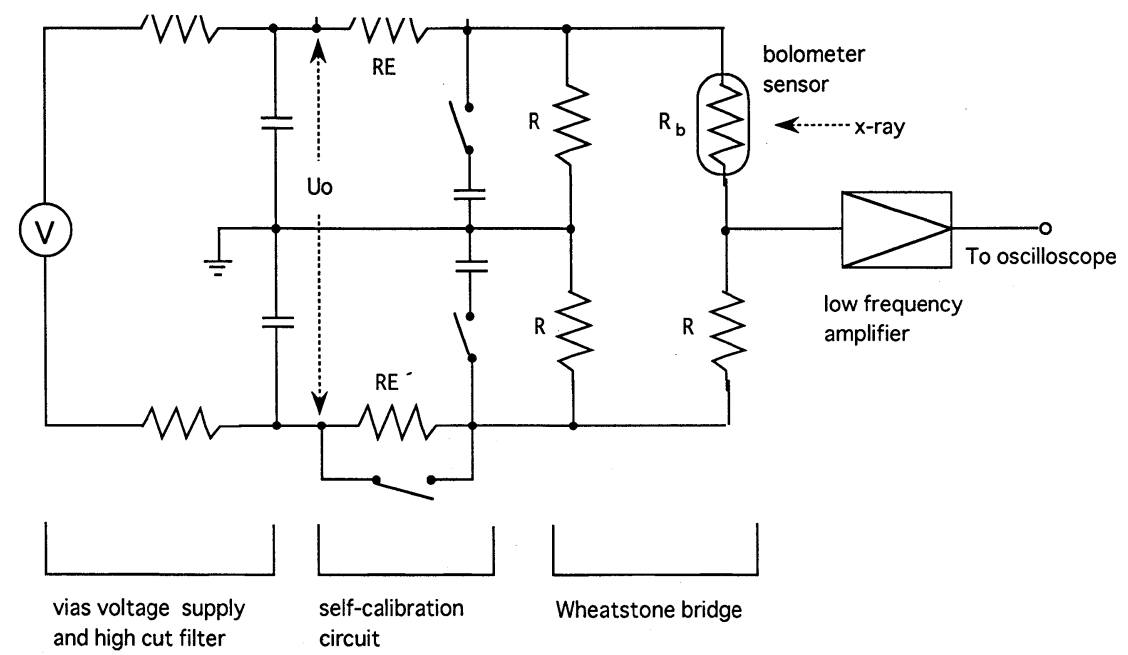

Fig. 1 Bolometer circuit is composed of 4 parts. Output voltage from the Wheatstone bridge is amplified by a low frequency amplifier which is composed of non-inverted op-amp. circuit. Four high speed relay-switches for absolute calibration of the sensor syncronously operate. The resisters $R E$ and $R E^{\prime}$ are current controllers for self calibration.

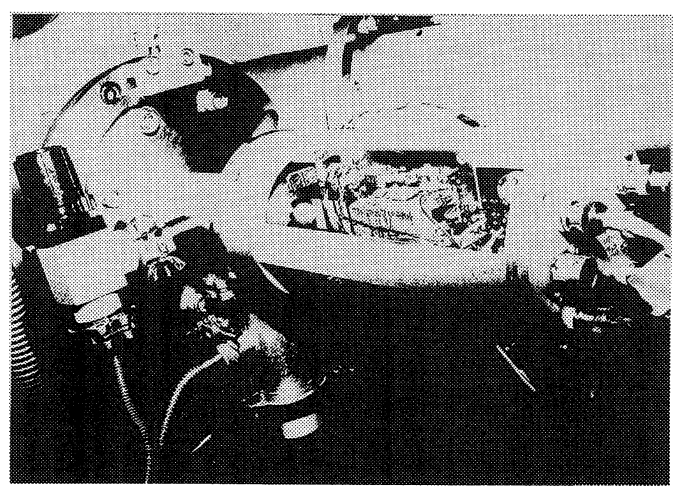

Fig. 2 Bolometer

る。ボロメーターの検出部はX線フィルターを 介してプラズマ生成チェンバーとは隔離された 小型の真空容器の中に納められている。

$<$ 検出部 $>$

Fig. 3に検出部の構造を示す。ポリイミド系 プラスチックフィルムKAPTON

$$
\left(\mathrm{N}-(\mathrm{CO})_{2}-\mathrm{C}_{6} \mathrm{H}_{2}-(\mathrm{CO})_{2}-\mathrm{C}_{6} \mathrm{H}_{4}-\mathrm{O}-\mathrm{C}_{6} \mathrm{H}_{4}\right)_{n}\left(7 \mu \mathrm{m}^{\mathrm{t}}\right)
$$

を基板としてX線入射側に $\mathrm{Au}$ の吸収体 $(1 \mathrm{~mm} \times$ $3 \mathrm{~mm} \times 4 \mu \mathrm{m}^{\mathrm{t}}$ )が, 裏面に測温抵抗体(断面積 $\left.1.5 \mu \mathrm{m}^{2} \times 0.129 \mathrm{~m}\right)$ が吸収体の占める範囲に収 まるようジグザグ構造で4チャンネル分配置さ れている。各チャンネル間はアルミニウム製の ヒートシンクを兼ねた支持構造体でサンドイッ チされ，チャンネル間の熱的な結合を押さえて

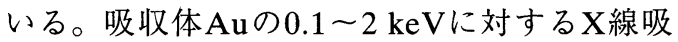
収特性はほぼ100\%で，これらの輻射に対して 平坦な分光感度特性が得られる。X線吸収によ る測温抵抗体の熱的な応答特性は吸収体と測温 抵抗体との熱緩和時間によって決まり, 計算か ら〜500 $\mu \mathrm{s}$ 程度となった。立ち下がり特性につ いては熱伝導による冷却時間によって決まる。 検出部の温度上昇は $7 \mathrm{erg}$ の入で〜 $0.01{ }^{\circ} \mathrm{K}$ 程度 であるから熱放射による冷却は無視でき，ほと んどの熱は伝導により散逸する。即ち, 吸収体 とKAPTONとの間の $0.1 \mu \mathrm{m}$ の Auコート層を 伝ってアルミニウム製の支持構造体に伝熱する ことにより熱緩和する。このとき冷却時間は一 $200 \mathrm{~ms}$ と見積もられた。

くブリッジ及び増幅部〉

ブリッジ部はホーイトストンブリッジ回路と 自己較正用回路(較正用低抵抗と高速リレー)か ら成る。通常は較正用抵抗 $R E, R E^{\prime}$ は回路に 


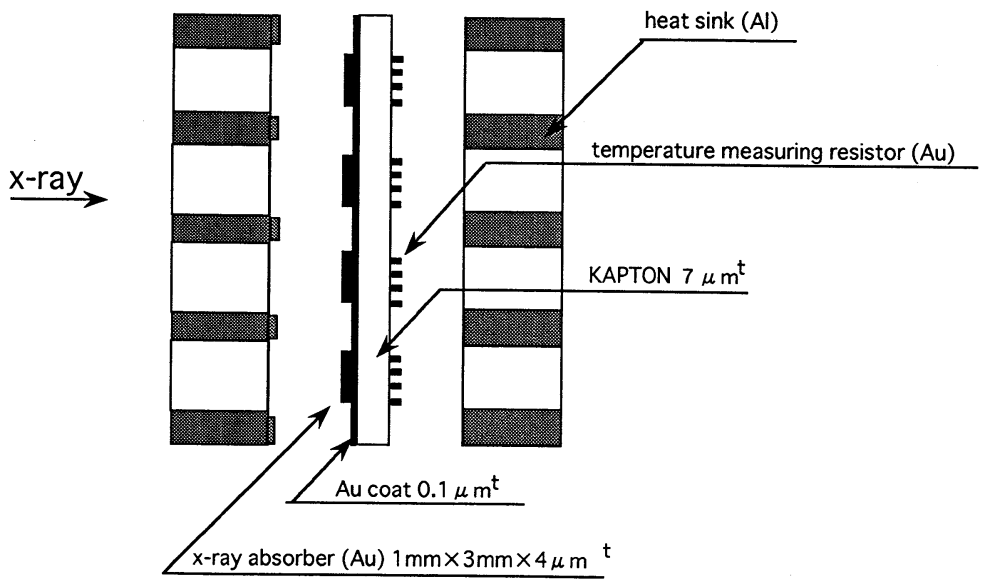

Fig. 3 Cross-sectional view of the bolometer sensor. X-ray absorber and thermo-resister for temperature mesurements are evaporated on polymer film (KAPTON). Thermal coupling between neiboring channels is prevented by contacting an aluminum heat sink with the gold heat conduction layer.

直列に接続されており, 高周波バイパスコンデ ンサーが付加されている。吸収体の温度上昇に よる測温抵抗体の抵抗上昇值を $\Delta R$, ブリッジ 駆動電圧を $U_{0}$, 抵抗值を図中の值としてブリッ ジ出力 $V_{0}$ は(1)式のようになる。ここで第1項は 測温抵抗体の温度上昇による抵抗值の増加の結 果生じる出力電圧で, 第2項は較正用抵抗 $R E$ と $R E^{\prime}$ の電圧降下に差がある場合の出力電圧に相 当するもので, ブリッジ出力のグランド電位が ノイズフィルター用のコンデンサーを介して影 響を受け， $U_{0} / 2(\mathrm{~V})$ からずれる結果生じる出力 電圧である。

$$
V_{0}=\frac{\Delta R}{4 R} U_{0}+\frac{5}{2} \frac{R E^{\prime}-R E}{R} U_{0}(\mathrm{~V})
$$

標準的な值として吸収体に5.0 ergのエネル ギーをボロメーターの応答時間よりも十分短い 時間に与えると測温抵抗体の温度上昇は $7.0 \times$ $10^{-3} \mathrm{~K}$ となり，このときのブリッジ出力は $28 \mu$ $\mathrm{V}$ と見積もれた。この出力を通常のオシロス コープで観測するため, 応答周波数 $10 \mathrm{~Hz}$ 付近 で最大值を持った狭帯域アンプのピーク増幅率 を標準值5万倍と設定した。

2.2 ボロメーター単体による絶対感度較正 ボロメーターの自己較正は次のように行っ
た。Fig. 1において外部パルス電源により較正 用各リレーは同時動作し, 較正用抵抗の両端を 短絡する。この動作によりブリッジ回路を流れ る電流はパルス的に増加し, ブリッジの各抵抗 でのジュール熱消費はわずかに増加する。熱容 量の差からブリッジ回路の金属被膜抵抗での温 度上昇は測温抵抗体に比べて無視できるので, 測温抵抗体のみを温度上昇させることができ る。リレー動作時に各測温抵抗体に与えられる エネルギー $E(\mathrm{erg})$ は測温抵抗体における消費電 力の変化とリレー動作時間幅 $\tau(\mathrm{s})$ の積として, (2)式のように計算できる。(自己較正時には4 chのうち $1 \mathrm{ch}$ 分をブリッジ平衡確認用に使用す るため, ここでは $3 \mathrm{ch}$ 分の等価な測温抵抗体が ブリッジ回路に並列接続されているとして計算 した。)

$$
\begin{aligned}
E=2 \cdot R E \cdot \frac{U_{0}^{2}}{R^{2}} \cdot \tau \times 10^{7}(\mathrm{erg}) \\
\left(\text { ただし }, R E=R E^{\prime}<<R_{\mathrm{b}}=R \text { とした }\right)
\end{aligned}
$$

熱緩和時間を考慮して較正用リレーは動作時間 幅 $\tau$ を $16 \mathrm{~ms}$ とした。空気による熱伝導損を避 けるためにボロメーターの検出部は真空容器に 取り付け, 圧力 $2 \times 10^{-4}$ Torrのもとで自己較正 


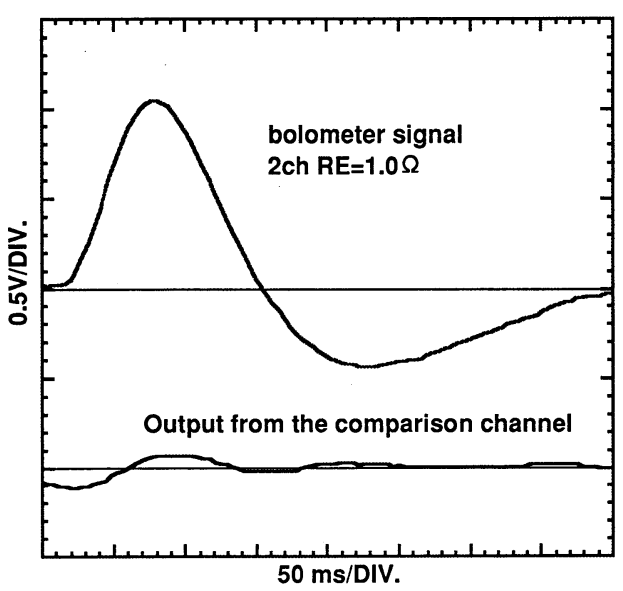

(a)

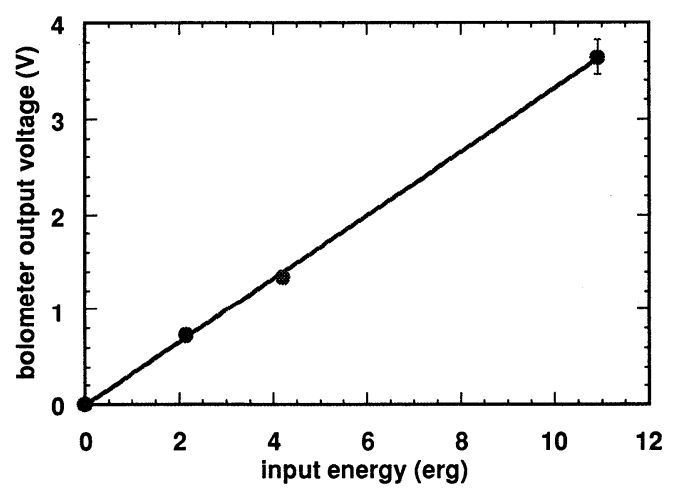

(b)

Fig. 4 (a) Equilibrium of Wheatstone bridge was confirmed. (b) Result of the self-calibration. A good linear response is obtained.

を行った。投入エネルギーは自己較正用抵抗值 を変えることにより変化させた。(1)式から明 らかなように自己較正時にはブリッジの平衡が 成り立っていなければ出力に誤差を生じる。ま

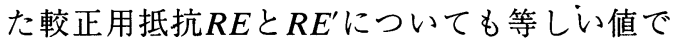
なければ出力に誤差を生じる。このため回路中 の抵抗值調整は注意深く行った。この調整を確 認するために $1 \mathrm{ch}$ 分の測温抵抗体を金属被膜抵 抗に取り替え, 出力を観測した。この結果を Fig. 4(a)に示す。増幅器の位相特性の関係から 得られた信号は一旦，正值を示した後，負にな り，やがて一定值となる。自己較正としてはこ の正信号のピーク値を用いた。信号の立ち上が
りも増幅器の特性を反映して $50 \mathrm{~ms}$ となってい る一方で信号の減衰時間は約 $250 \mathrm{~ms}$ で, モデル 計算にほぼ一致する。またダミー抵抗を挿入し た場合にも僅かに出力があるものの本信号の約 15 分の 1 以下に押さえられている。較正用投入 エネルギーをさらに大きくすることで相対的に この誤差原因は抑えられ, 較正誤差は最終的に $5 \%$ となった。較正用抵抗の值を変化させ，投 入エネルギーに対する出力の結果をFig. 4(b)に 示す。良好な線形特性が得られている。ここで 増幅回路の最大増幅率(5万倍)をもとに得たボ ロメーター自体の感度は $6.6 \mu \mathrm{V} / \mathrm{erg}$ であった。

3. ボロメーターを使用したフィルムの絶対 感度較正

\section{1 実験条件}

今回絶対感度曲線を測定したのはILFORD 社Q-plate と Kodak社 101-05plateである。従来 軟 $\mathrm{X}$ 線用フィルムとして広く使われてきた Kodak社製101-01(または101-07) フィルムは 1991年7月をもって製造中止となったが，これ に代わって現在101-05plateが入手可能である。 またQ-plateは粒子検出用として核計測の分野 で広く用いられて来たものである。両プレート 共にガラス板の上に感光乳剤が塗布されてお り, 従来のフィルムに比べて取り扱いが比較的 容易になっている。X線プレートの感度較正実 験にはX線源としてレーザープラズマを用い た。用いたレーザーは大阪大学レーザー核融合 研究センター激光 MII号の1ビームで, 波長 $351 \mathrm{~nm}$, パルス幅 $500 \mathrm{ps}$, エネルギー0.2〜25 J, 照射強度 $9.0 \times 10^{11} \sim 1.1 \times 10^{13} \mathrm{~W} / \mathrm{cm}^{2}$ であった。 レーザー入射角は $45^{\circ}$ とし，この時のスポット 径は $200 \times 280 \mu \mathrm{m}$ のほぼ棈円形とした。ター ゲットは厚さ $25 \mu \mathrm{m}$ の平板 $\mathrm{Cu}$ 用い, $\mathrm{Cu}$ プラ ズマからのLバンド放射 $1.1 \mathrm{keV}$ ，エネルギー 幅 $+0.1 ，-0.06 \mathrm{keV}$ 使用した。1.1 keV以下 の低エネルギーX線成分をカットするために $1 \mu \mathrm{m}^{\mathrm{t}}$ のアルミニウムフォイルをフィルターと して用いた。このフィルターはまたレーザー散 乱光やプラズマ粒子がボロメーター上に飛来す 
るのを抑え, 真空隔離する役目も持つ。ボロメー ターの自己較正を確認し, 併せてX線プレート 較正の信頼性を増す目的で, 別個に絶対較正さ れたダイヤモンド検出器を併用した。この検出 器の前にも同様のアルミニウム $1 \mu \mathrm{m}^{\mathrm{t}}$ が置かれ ている。今回はダイヤモンド検出器の特徵であ る時間分解計測は生かさず, 時間積分值である エネルギー計測で比較したので，ボロメーター やX線プレートの感度を求める際はダイヤモン ド検出器からの出力を時間積分し, 出力電荷量 に等価な量で比較した。以下の記述においてこ の電荷量を表すのに使用した単位は負荷 $50 \Omega に$ おける出力電圧と時間幅の積 $(\mathrm{nVs})$ とした。 $\left(1 \mathrm{nVs}\right.$ は $2 \times 10^{-11}[\mathrm{C}]$ に相当する。)プレートの 露光量を幅広くとるため, レーザーエネルギー を変化させるだけでなくプラズマ光源とプレー トの距離を $R=3628 \mathrm{~mm}$ と $1178 \mathrm{~mm}$ の 2 力所と した。このとき較正基準となるボロメーターと ダイヤモンド検出器の位置は固定したままで あった。X線の角度分布はランバート分布(い わゆる $\cos \theta$ 分布。 $\theta$ は夕ーゲット垂直からの 角度)に従うと仮定した。プラズマの膨張に伴 い, レーザーパルス幅500 ps 間に生じる夕ー ゲット垂直方向の発光域広がりは50 $\mu \mathrm{m}$ 程度と 見積もられるのに対し，レーザースポットは $200 \times 280 \mu \mathrm{m}$ であるのでほぼこの仮定は妥当と 考えられる。なお，等方分布だと仮定した時と の差から生じる誤差はプレートの較正で7\%程 度である。実験に用いたプレートの製造番号は Q-plateがBatch 62D-PQA-119，101-05plateが CAT.193 6293であった。露光面のサイズはプ レート上で $3 \mathrm{~mm} \times 10 \mathrm{~mm}$ で, 像エッジ部の現 像促進現象による見かけ上の黒化度上昇 ${ }^{15)}$ は 抑えるようにした。露光されたプレートは両方 とも Table Iに示す手順に従って現像を行った。 露光したフィルムの光学濃度は1次元のマイク ロデンシトメーター(サクラ model PDM-5 microdensitometer N.A =0.10)で測定した。

\section{2 測定結果}

まずX線ボロメーターとダイヤモンド検出器
Table I Plate developing procedure.

\begin{tabular}{ll}
\hline \hline pre-soaking & $20^{\circ} \mathrm{C}$ pure water $2 \mathrm{~min}$. \\
developing & $20^{\circ} \mathrm{C}$ Kodak D-19 duoble \\
& dilition 4 min. \\
stop & $20^{\circ} \mathrm{C}$ pure water $30 \mathrm{sec}$. \\
fixation & $20{ }^{\circ} \mathrm{C}$ Fuji sulper fix $3 \mathrm{~min}$. \\
soaking & 7 min. \\
drywell & Fuji drywell at room tem- \\
& perature 30 sec. \\
dry & at room temperature in still air \\
\hline
\end{tabular}

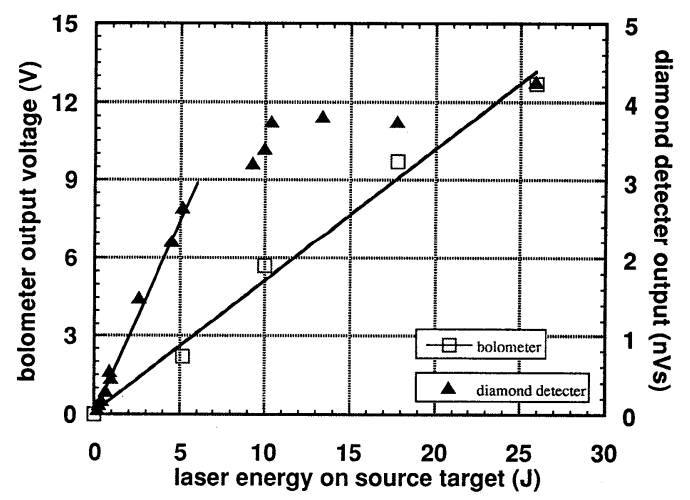

Fig. 5 Outputs from the bolometer and diamond detecter versus the incident laser energy on the $\mathrm{Cu}$ source target. As for as conversion effciency of the laser tox-rays is independent on laser irradiance, quantity on the holizontal axis is equivalent to incident $\mathrm{x}$-ray energy on each sensor. This hypothesis can be confirmed by linear response of the bolometer.

の照射レーザーエネルギーに対する線形性を調 べた。結果をFig. 5に示す。横軸は照射レーザー エネルギー, 縦軸はボロメーターとダイヤモン ド検出器の出力である。光源として用いている 準単色X線へのレーザーからの变換効率がレー ザー照射強度に対して変化せず一定の值を持つ という前提においてこのプロットは妥当であ る。使用したレーザーの波長やパルス幅，照射 強度を考慮するとレーザー吸収率は95\%以上 でほぼ一様と考えられる ${ }^{16)}$ が, 吸収エネルギー からX線への変換効率はまだ詳しく調べられて いない。しかし測定結果から次のようなことが 判る。ボロメーターの自己較正の結果からボロ 


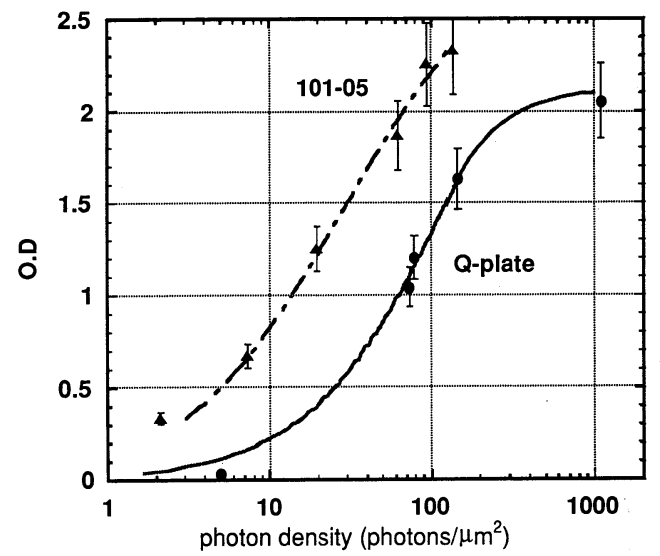

Fig. 6 Dependence of ILFORD Q-plate and Kodak 101-05 plate on $\mathrm{x}$-ray exposure obtained by the $\mathrm{x}$-ray bolometer. Photon energy is 1.1 $\mathrm{keV}$ of $\mathrm{Cu}$ L-lines. In the lower exposure case, output from the diamond detector was used because of better signal-to-noise ratio.

メーター出力は入射エネルギー量に比例して増加 する領域内である事が判っているから, Fig. 5 の関係から放出された準単色X線エネルギーは レーザーエネルギーに比例して増加しているも のと考えられる。即ち本実験の条件下において レーザーからX線への変換効率がほぼ一定であ り，グラフの横軸をX線のエネルギー量に一定 の比例係数で読み替えることが出来る。この推 察よりダイアモンド検出器はX線の入力エネル ギーが小さい時には線形性が保たれているもの の, 入力エネルギーの大きな所では飽和傾向を 示すことが判った。ダイアモンド検出器をボロ メーターにより絶対値較正して得られた感度は $2.59 \times 10^{-4} \mathrm{~A} / \mathrm{W}$ となった。ボロメーターにより 較正したX線プレートの絶対感度曲線 ( $\gamma$ 曲線) を示す。ここでいう光学濃度はフォグレベルを 差し引いた值である。各測定デー夕点を結ぶ曲 線はHenke ${ }^{17)}$ の薄エマルジョンモデルから最適 パラメーターを決定したものである。Fig. 6 から明らかなように101-05plateの方がQplateに 比べ約4倍の感度を持ち, 飽和点も高い值を示 している。
3.3 ボロメーターによるダイヤモンドの絶 対感度較正

ダイヤモンド光電素子は, シリコンなどの半 導体検出器と比べて, 1)動作原理上空乏層など の問題がない，2)低Z物質のため侵入長が長く とれ表面再結合等の影響が少ない, などの理由 により低エネルギー領域から高エネルギー領域 まで分光感度が一定となる特長を持っている。 この検出器の出力電流密度Jはキャリヤー密度 $n$, 移動度 $\mu$, 電界強度 $\mathrm{E}$ の積となり, 小キャ リヤー注入時にはキャリヤー密度すなわち入射 光量に比例したものとなる。

さて, 入射光量の増大に伴いキャリヤー密度 が増加すると, キャリヤー・キャリヤー散乱に よる移動度の低下が検出器の感度を減少させ る。この散乱過程による移動度はダイヤモンド 内の電子, 正孔の有効質量より計算され以下の ようになる ${ }^{18)}$

$$
\begin{aligned}
& \mu_{\mathrm{ccs}}=3 \times 10^{16} \frac{T^{3 / 2}}{\sqrt{n_{\mathrm{e}} n_{\mathrm{p}}}} \\
& \times \frac{1}{\left[\ln \left(1+1.77 \times 10^{8} \frac{T^{2}}{\left(n_{\mathrm{e}} n_{\mathrm{p}}\right)^{1 / 3}}\right)\right]}\left[\frac{\mathrm{cm}^{2}}{V \cdot \mathrm{s}}\right]
\end{aligned}
$$

ここで $n_{\mathrm{e}}$ は電子の数密度, $n_{\mathrm{p}}$ は正孔の数密度, Tは温度である。

実効的な移動度 $\mu_{\mathrm{eff}}$ は小キャリヤー時の $\mu_{0}$ と この $\mu_{\mathrm{ccs}}$ の調和平均になる。本研究でダイヤモ ンド検出器が使用された条件ではキャリヤー密 度が $10^{17} \mathrm{~cm}^{-3}$ を越えるため, 線形領域から飽 和領域にかけて動作していることになる。

Fig. 7はボロメー夕により測定されたX線量 に対するダイヤモンド出力結果を表わしてい る。図中の点線は, キャリヤー・キャリヤー散 乱を考慮したモデルにより，小キャリヤー時の 感度 $S_{0}$, 移動度 $\mu_{0}$ をパラメータとしてフィッ ティングした結果である。このモデル中でキャ リヤー密度はボロメータで測定した入射 $X$ 線光 量から見積もってある。Table IIはその結果を 
Calibration of the diamond detector with bolometer at $h v=1.13 \mathrm{keV}$

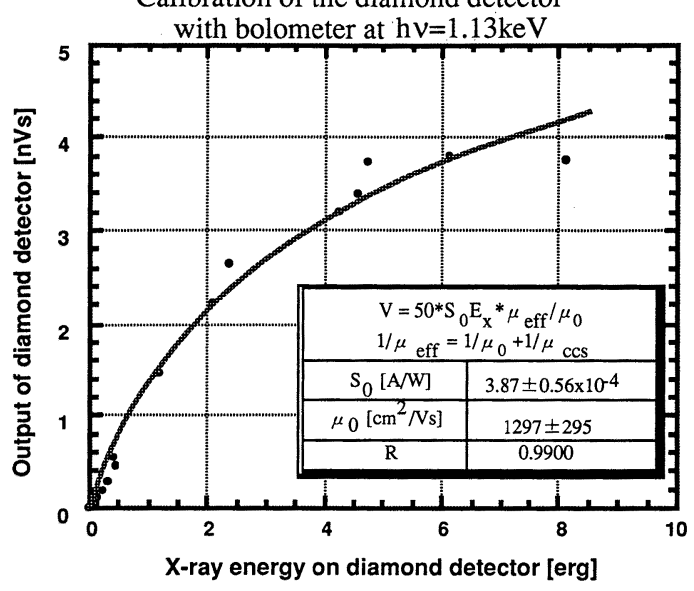

Fig. 7 Calibration of the diamond detector with bolometer at photon energy $1.13 \mathrm{keV}$.

Table II The sensitivity, mobility and carrier life time calculated with the results of the Bolometer.

\begin{tabular}{lcc}
\hline \hline & $\begin{array}{l}\text { parameters estimated } \\
\text { from the Bolometer }\end{array}$ & $\begin{array}{l}\text { parameters from } \\
\text { the previovs laser } \\
\text { experiments or } \\
\text { reference value }\end{array}$ \\
\hline sensibility $S_{0}$ & $\begin{array}{c}3.87 \pm 0.56 \times 10^{-4}[\mathrm{~A} / \mathrm{W}] \\
\text { mobility } \mu_{0}\end{array}$ & $\begin{array}{c}3.82 \times 10^{-4}[\mathrm{~A} / \mathrm{W}] \\
\text { carrier life time }\end{array}$ \\
\hline \hline
\end{tabular}

まとめたもので，以前に求めた $h \nu=100 \sim 284$ $\mathrm{eV}$ における感度較性值 ${ }^{13)}$ や文献值 ${ }^{7)}$ ともに示 している。これからわかるように，今回の值は 以前に求められた移動度, 感度とも非常に良い 一致をしていることがわかる。また，感度につ

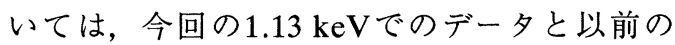
$100 \sim 280 \mathrm{eV}$ のデータがほぼ一致したことでダ イヤモンドの特質である分光感度のフラット性 も示されたことになる。また，表には感度 $S_{0}$, 移動度 $\mu_{0}$, 平均電子.正孔対生成エネルギーか ら求められるキャリヤー寿命の計算値も合わせ て示してある。この值は，やはり以前独立して 行なわれた超短パルスレーザー励起による寿命 測定值 ${ }^{13)}$ とほぼ一致しており，今回使用して いるモデルの正当性を裏付けている。

\section{4. まとめ}

軟X線絶対計測用ボロメーターの開発を行 い，X線プレートの絶対感度較正実験に適用し た。そしてILFORD社Q-plate, Kodak社101-

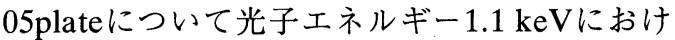
る絶対感度計測を行った。今回の実験ではボロ メーターの特徵である絶対計測と自己較正機能 により軟X線領域での絶対感度較正が比較的簡 単に出来るようになった。さらにダイヤモンド 検出器との併用によりボロメーターのS $/ \mathrm{N}$ 比が 問題になるような小さな投入エネルギー時にお いても絶対值計測が行えた。ボロメーターの絶 対感度較正の妥当性を確認するためボロメー ターを基準として得たダイヤモンド検出器の絶 対感度は，別個に測定された感度に良く一致し た。

ボロメーターは今後，さらに低ノイズ化を図 る事により単体でも十分に軟X線絶対計測器と して利用できるほか，多チャンネル化を図り， 回折格子との組み合わせにより分光計測にも対 応できると期待されている。

\section{謝辞}

ボロメーターの製作にあたっては，大阪大学 レーザー核融合研究センター計測研究室, 杉本 吉隆君，戸川金美君の協力を得ました。またX 線プレートの較正実験には白神宏之助手はじ め，レーザーオペレーショングループの協力を 得ました。哚く感謝の意を表します。

\section{参 考 文 献}

1) 例えばG. D. Kubiak, et. al.,: J. Vac. Sci Technol. B9 (1991) 3184 とその参考文献.

2) R. C. Elton: X-ray Lasers (Academic Press, Boston, 1991).

3) R. H. Price: American Institure of Physics, Conference Proceedings 75 (1981) 189.

4) 西村博明: 核融合研究 63 (1990) 4.

5) 三浦永祐, 富江敏尚：レーザー研究 21 (1993).

6) R. H. Day, P. Lee, E. B. Saloman and D. J. Nagel: J. Appl. Phys. 52 (1981) 6965.

7) D. R. Kania, R. J. Bartlett, R.S. Wagner, R. 
B. Hammond and P. Pianetta, Appl. Phys. lett, 44 (1984)1059; R. B. Hammond, R. S. Wagner and N. G. Paulter: InP: Fe picosecond photoconductors, proceedings of SPIF vol. 439 "Picosecond Optoelectronics" p192 (1983).

8) R. J. Fonck: Multichannel Extreme UV Spectroscopy of High Twemperature Plasmas ACS Symp. Ser. 236 (1983) 277.

9) B. L. Henke, J. P. Knauer and Premaratne: J. Appl. Phys. 52(3) (1981).

10) H. Nishimura, K. Eidmann, K. Sugimoto, W. Schwanda, T. Toyoda, K. Taniguchi, Y. Kato and S. Nakai: J. X-ray Science and technol. 3 (1991) 14.

11) K. Eidmann, T. kishimoto, PHerrmann, J. Mizui, R. Pakula, R. Sigel and S. Witkowski: Laser and Particle Beams, 4 (1986).

12) D. R. Kania, L. Pan, H. Kornblum, P. Bell, O. N. Landen and P. Pianetta: Rev. Sci. Instrum. 61 (1990) 2675.
13) 米田仁紀：ダイヤモンドを用いたレーザー生 成プラズマの超高時間分解X線計測, 平成 4 年 度科学研究補助金 (重点領域研究)「X線結像光 学」研究成果報告書 (研究代表者山下広順) p369 (平成5年7月).

14) P. Betzler: Mehrfachbolometer ruer hohe Raumaufloesung, M. P. Q /Germany.

15) J. C. Dainty and P. Shaw: Image Science, p53 Academic Press, London/New York/San Fransisco, 1974.

16) H. Nishimura, H. Takabe, K. Kondo, T. Endo, H. Shiraga, K. Sugimoto, T. Nishikawa, Y. Kato and S. Nakai: Phys. Rev. A43 (1991) 3073.

17) B. L. Henke, S. L. Kwok, et. al.,: J. Opt. Soc. Am. B1, 6 (1984) 818.

18) S. C. Choo: IEEE Trans. Electron Devices, ED-19 (8), 954-966 (1972). 